\title{
DAMPAK PANDEMI COVID-19 TERHADAP PENERAPAN PEMBELAJARAN ONLINE DI INDONESIA: SEBUAH TINJAUAN PUSTAKA
}

\author{
Muttaqin Choiri, Mutiara Cahyani Fajrin ${ }^{2}$, Tanti Alfrida Novianti, \\ Eva Nur Kholidah Putri $\mathrm{Ms}^{4}$ \\ ${ }^{1}$ Hukum Bisnis Syariah Fakultas Keislaman Universitas Trunojoyo Madura, ${ }^{2}$ Sistem Informasi \\ Fakultas Teknik Universitas Trunojoyo Madura, ${ }^{3,4}$ Pendidikan Guru Sekolah Dasar Fakultas \\ Pendidikan Universitas Trunojoyo Madura \\ Imuttaqin.choiri@trunojoyo.ac.id, ${ }^{2}$ mutiaracf99@gmail.com, ${ }^{3}$ tantioke53@gmail.com, \\ ${ }^{4}$ kholidahnureva@gmail.com
}

\begin{abstract}
Abstrak: Pandemi COVID-19 adalah krisis kesehatan yang sedang menjadi perhatian negaranegara di dunia saat ini. COVID-19 merupakan penyakit yang belum pernah teridentifikasi sebelumnya pada manusia yang disebabkan oleh virus Sars-CoV-2. Menyebarnya COVID-19 di Indonesia menyebabkan Indonesia perlu melakukan pembatasan sosial untuk mencegah meningkatnya jumlah pasien COVID-19. Pembatasan sosial menyebabkan terganggunya beberapa aktivitas di berbagai bidang, terutama di bidang pendidikan. Kajian yang dilakukan dalam penyusunan paper mengacu pada 10 artikel terbaru pada tahun 2020 yang membahas tentang permasalahan yang sedang terjadi saat ini, berkaitan dengan dampak COVID-19 terhadap pembelajaran online menggunakan metode Systematic Literature Review. Proses pengkajian 10 artikel ini diklasifikasi menjadi 3 kelompok sub topik. Berdasarkan kajian yang telah dilakukan, diperoleh hasil pembelajaran online di era pandemi COVID-19 sangat memacu pertumbuhan pembelajaran online yang memudahkan dalam proses belajar mengajar, namun jika dinilai dari perubahan sikap siswa, sistem tersebut lebih menunjukkan sisi negatif, sehingga diperlukan adanya evaluasi terkait pembelajaran online oleh pemerintah
\end{abstract}

Kata kunci: Covid-19, pembelajaran online, Systematic Literature Review(SLR)

\begin{abstract}
COVID-19 pandemic is a health crisis that currently has been becoming the concern of countries in the world. COVID-19 is a disease that has never been previously identified in humans, which is caused by the Sars-CoV-2 virus. The spread of COVID-19 in Indonesia has made this country need to do social distancing to prevent the increasing number of COVID-19 patients. This social distancing has disrupted several activities in various fields, especially in the field of education. The paper done refers to 10 current articles in 2020 that discuss current problems, with the COVID-19 impact of online learning using Systematic Literature Review method. The review process of these 10 articles was classified into 3 sub-topic groups. Based on the studies that had been carried out, the result of online learning in the COVID-19 pandemic era has greatly accelerated the growth of online learning which eases the teaching and learning process. However, if it is judged by the changes in the students' attitudes, the system shows more of negative sides. Therefore, there should be an evaluation related to the online learning by the government.
\end{abstract}

Keywords: Covid-19, online learning, Systematic Literature Review (SLR)

\section{PENDAHULUAN}

Pandemi COVID-19 adalah krisis kesehatan yang sedang menjadi perhatian negara-negara di dunia saat ini. Indonesia merupakan salah satu negara yang terdampak pandemi COVID-19, sehingga menyebabkan adanya pembatasan sosial untuk mencegah meningkatnya jumlah pasien COVID-19 yang mengganggu beberapa aktivitas di berbagai bidang, seperti dalam bidang sosial, ekonomi, pariwisata, dan pendidikan. Seperti yang tertera pada Surat Edaran (SE) pemerintah tanggal 18 Maret 2020, sebagai tanggapan untuk menekan angka penyebaran COVID-19 perlu adanya penundaan segala bentuk aktivitas untuk sementara waktu, baik aktivitas diluar maupun didalam ruangan utamanya di bidang pendidikan (Dewi, 2020). Disamping itu Kemendikbud RI juga mengeluarkan Surat Edaran Nomor 4 Tahun 2020 tanggal 24 Maret 2020, tentang Pelaksanaan Kebijakan Pendidikan Dalam Masa Darurat Penyebaran COVID-19, berisi tentang pelaksanaan proses belajar mengajar yang dilaksanakan di rumah secara daring agar siswa memiliki pengalaman belajar yang bermakna (Dewi, 2020). 
Mengingat perkembangan teknologi yang pesat pembelajaran jarak jauh sangat memungkinkan dilakukan oleh tenaga pengajar dan pelajar untuk saling berinteraksi, dengan memanfaatkan internet dalam pembelajaran secara virtual yang lebih dikenal dengan kelas online atau e-learning. Pembelajaran online ini dapat dilakukan dengan memanfaatkan beberapa aplikasi e-learning serta aplikasi video conference, seperti google classroom, schoology, edmodo, google meet, zoom dan lain-lain. Pembelajaran e-learning memiliki beberapa kelebihan, diantaranya dapat membantu siswa dalam mengerjakan berbagai tugas, menumbuhkan motivasi belajar siswa, membimbing siswa dalam menggunakan gadget pada tujuan yang positif, serta melatih daya kreatifitas siswa (Jayawardana, 2017).

Berdasarkan permasalahan di atas, maka pada penelitian ini kami melakukan kajian pustaka tentang pembelajaran yang dilakukan secara online ketika pandemi COVID-19. Menggunakan Metode Systematic Literature Review, dengan mengumpulkan penelitian sebelumnya mengenai dampak penerapan pembelajaran online di era pandemi COVID-19, kemudian melakukan klasifikasi terkait topik penelitian. Sehingga, hasil kajian pustaka dari penelitian ini nantinya dapat digunakan sebagai acuan untuk penelitian selanjutnya mengenai dampak penerapan pembelajaran online di era pandemi COVID-19, terutama di Indonesia.

Dengan demikian, berdasarkan tujuan tersebut, maka research question yang akan dijawab pada penelitian ini, sebagai berikut?

(1) Apakah adopsi pembelajaran online di era pandemi COVID-19 memacu adanya pertumbuhan pembelajaran online, terutama di Indonesia?

(2) Bagaimana Evaluasi Kebijakan Pembelajaran Online?

(3) Bagaimana pertumbuhan sikap siswa pada sistem belajar online?

Untuk menjawab research question tersebut, maka pada penelitian ini akan mengadopsi metodologi Systematic Literature Review (SLR) yang akan dijelaskan berikut ini.

\section{METODE}

Jenis penelitian yang digunakan dalam penelitian ini adalah riset kepustakaan. Penelitian ini akan mengambil data terkait dampak pandemi COVID-19 terhadap penerapan pembelajaran online dalam beberapa artikel penelitian yang sudah terakreditasi. Riset pustaka merupakan suatu penelitian yang melakukan kegiatan yang berkaitan dengan metode pengumpulan berbagai data pustaka, membaca, mencatat, dan mengolah bahan pustaka tanpa adanya kegiatan riset lapangan.

Target/Sasaran penelitian ini ditujukan kepada seluruh masyarakat Indonesia, pemerintah Indonesia sebagai cerminan terhadap bidang pendidikan di era pandemi COVID-19 terkini, dan untuk peneliti yang akan melakukan penelitian terkait dampak pandemi COVID-19 terhadap penerapan pembelajaran online di Indonesia pada masa-masa mendatang.

Waktu yang dibutuhkan peneliti dalam penelitian ini sejak tahap pengumpulan data hingga ke tahap submit artikel yang terhitung kurang lebih 7 minggu atau 2 bulan yakni pada tanggal 30 Oktober 2020 hingga 12 Desember 2020.

Metode yang digunakan dalam penelitian ini adalah metode Systematic Literature Review (SLR). Metode Systematic Literature Review (SLR) adalah metodologi pada penelitian atau riset tertentu yang dilakukan untuk mengumpulkan serta mengevaluasi penelitian yang berkaitan dengan fokus topik tertentu. Preferred Reporting Items for Systematic Reviews and Meta-analyses (PRISMA) adalah pedoman yang digunakan pada Systematic Literature Review. Yang tersusun dalam lima tahapan, yang diilustrasikan pada gambar 1 . 


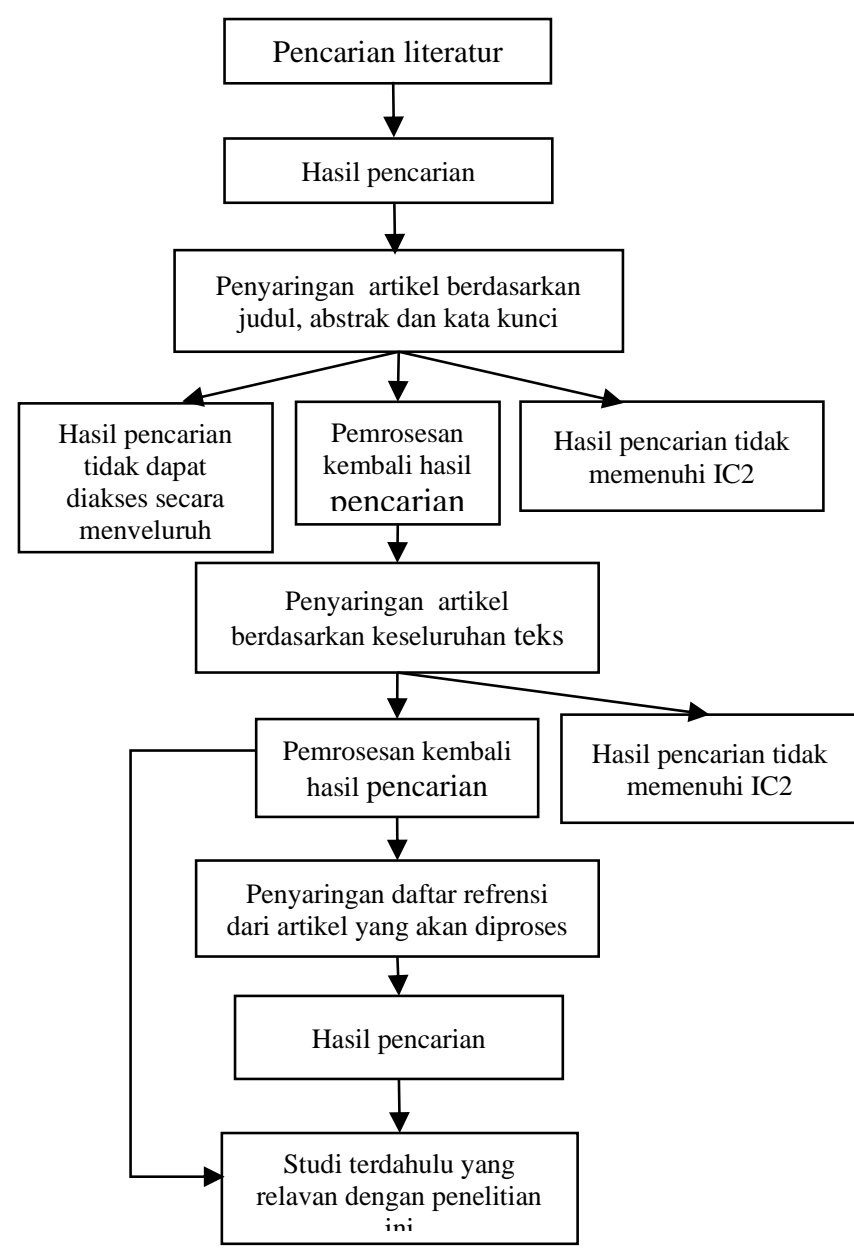

Gambar 1. Tahapan SLR dengan pedoman PRISMA

\section{Mendefinisikan kriteria kelayakan}

Tahap pertama untuk melakukan kajian literatur adalah dengan mendefinisikan kriteria kelayakan literature, hal tersebut ditentukan dengan kriteria inklusi (IC). Pada penelitian ini menentukan ada 2 kriteria kelayakan dari artikel yang akan dikaji yaitu:

IC1: Artikel adalah hasil dari riset yang menggunakan Bahasa Indonesia.

IC2: Tujuan dari artikel adalah melakukan penelitian mengenai dampak COVID-19 terhadap pembelajaran online yang ada di Indonesia.

\section{Mendefinisikan Sumber informasi}

Tahap kedua, dilakukan dengan mendefinisikan sumber informasi melalui pencarian literatur pada beberapa indeks cendekia seperti google scholar dan berbagai jurnal yang memuat artikel bertema dampak pembelajaran online di era pandemi Covid-19. Selain itu dilakukan pencarian artikel dengan melakukan analisis pada referensi yang terdapat artikel yang masuk pada kriteria inklusi, hal ini bertujuan untuk menemukan artikel lain yang berhubungan dengan penelitian ini.

\section{Pemilihan Literature}

Pada tahap ketiga yaitu pemilihan literature, berikut adalah hal-hal yang perlu dilakukan:

Menentukan key word/ kata kunci

Melakukan eksplorasi artikel, pemilihan judul, abstrak, dan kata kunci pada artikel yang telah didapatkan pada tahap pendefinisian kriteria kelayakan.

Membaca artikel secara lengkap atau parsial, kemudian menetukan apakah artikel tersebut layak dimasukkan dalam kajian berikutnya atau tidak.

Menemukan studi terkait lainnya dengan mengkaji ulang daftar referensi dari artikel terpilih. Artikel yang berelasi dengan penelitian pada daftar referensi akan dikaji ulang dengan melakukan tahapan 3 sampai 4.

Kata kunci yang digunakan dalam menentukan artikel yang dipilih antara lain: COVID-19, dampak COVID-19, pembelajaran online di masa pandemi COVID-19, dan sistem pendidikan di masa pandemi COVID-19.

\section{Pengumpulan Data}

Pada tahap keempat adalah pengumpulan data, dimana dilakukannya pembuatan formulir ekstraksi yang berisi metadata dari artikel yang telah dikumpulkan seperti nama penulis, judul, tahun, nama jurnal, kata kunci, metode yang digunakan, objek penelitian dan kesimpulan. Dan selanjutnya setiap artikel akan dicatat metadatanya dengan menggunakan formulir tersebut.

\section{Pemilihan Item Data}

Tahapan kelima adalah pemilihan item data, yaitu dilakukan dengan mengelompokkan topik penelitian mengenai dampak COVID-19 terhadap pembelajaran online. Topik-topik yang telah diklasifikasikan adalah sebagai berikut:

1. Topik yang membahas ulasan literatur tentang pandemi COVID-19 (ID1).

2. Topik yang membahas pembelajaran online di masa pandemi COVID-19 (ID2).

3. Topik yang membahas dampak pembelajaran secara online di era pandemi COVID-19 (ID3).

4. Topik yang membahas mengenai objek instansi pendidikan dalam melakukan pembelajaran online di masa pandemi COVID-19 (ID4). 
Klasifikasi ini ditentukan berdasarkan kajian dari topik-topik dampak pembelajaran online di era pandemi COVID-19. Berikut ini merupakan hasil pengumpulan data berdasarkan kualifikasi yang telah ditetapkan.

Tabel 1. Ringkasan Hasil Pengumpulan Data.

\begin{tabular}{|c|c|c|c|c|c|}
\hline Artikel & Desain & Sampel & $\begin{array}{c}\text { Prosedur } \\
\text { Pengumpulan } \\
\text { Data }\end{array}$ & Hasil & Rekomendasi \\
\hline $\begin{array}{l}\text { (Karo, } \\
2020)\end{array}$ & $\begin{array}{l}\text { Studi } \\
\text { Literatur }\end{array}$ & $\begin{array}{l}\text { Artikel } \\
\text { mengenai } \\
\text { Perilaku } \\
\text { Hidup Bersih } \\
\text { serta Sehat. }\end{array}$ & $\begin{array}{l}\text { Data yang } \\
\text { dikumpulkan } \\
\text { untuk menyusun } \\
\text { artikel, } \\
\text { berdasarkan } \\
\text { beberapa artikel } \\
\text { tentang perilaku } \\
\text { hidup sehat dan } \\
\text { pencegahan } \\
\text { penyebaran Virus } \\
\text { COVID-19 oleh } \\
\text { Kemenkes RI. }\end{array}$ & $\begin{array}{l}\text { Pencegahan penularan } \\
\text { virus ini dapat dicegah } \\
\text { dengan mengerakkan } \\
\text { Perilaku Hidup Bersih } \\
\text { dan Sehat (PHBS), } \\
\text { misalnya mencuci } \\
\text { tangan dengan cara yang } \\
\text { benar, memperhatikan } \\
\text { adab ketika batuk, dan } \\
\text { selalu memperhatikan } \\
\text { imunitas dan kesehatan } \\
\text { badan. Badan yang sehat } \\
\text { memiliki imunitas yang } \\
\text { kuat, sehingga tidak } \\
\text { akan mudah terinfeksi } \\
\text { Covid-19. }\end{array}$ & $\begin{array}{l}\text { Menghimbau } \\
\text { masyarakat } \\
\text { untuk selalu } \\
\text { menerapkan } \\
\text { prilaku hidup } \\
\text { bersih dan } \\
\text { sehat, karena } \\
\text { kesadaran } \\
\text { masyarakat } \\
\text { mengenai } \\
\text { perilaku } \\
\text { tersebut dapat } \\
\text { mempengaruhi } \\
\text { penurunan } \\
\text { penyebaran } \\
\text { penyakit } \\
\text { Covid-19. }\end{array}$ \\
\hline $\begin{array}{l}\text { (Telau } \\
\text { mbanua } \\
\text {, 2020) }\end{array}$ & $\begin{array}{l}\text { Mengan } \\
\text { alisis } \\
\text { secara } \\
\text { kualitati } \\
\text { f dan } \\
\text { disimpul } \\
\text { kan } \\
\text { dengan } \\
\text { cara } \\
\text { deduktif } \\
\text {. }\end{array}$ & $\begin{array}{l}\text { Hukum } \\
\text { tentang } \\
\text { kekarantinaa } \\
\text { n kesehatan } \\
\text { di Indonesia. }\end{array}$ & $\begin{array}{lr}\text { Data } & \text { yang } \\
\text { diperoleh } & \text { dari } \\
\text { hukum normatif } \\
\text { dengan } \\
\text { menggunakan } \\
\text { ketiga bahan } \\
\text { hukum yakni } \\
\text { bahan hukum } \\
\text { primer, sekunder, } \\
\text { dan tersier. }\end{array}$ & 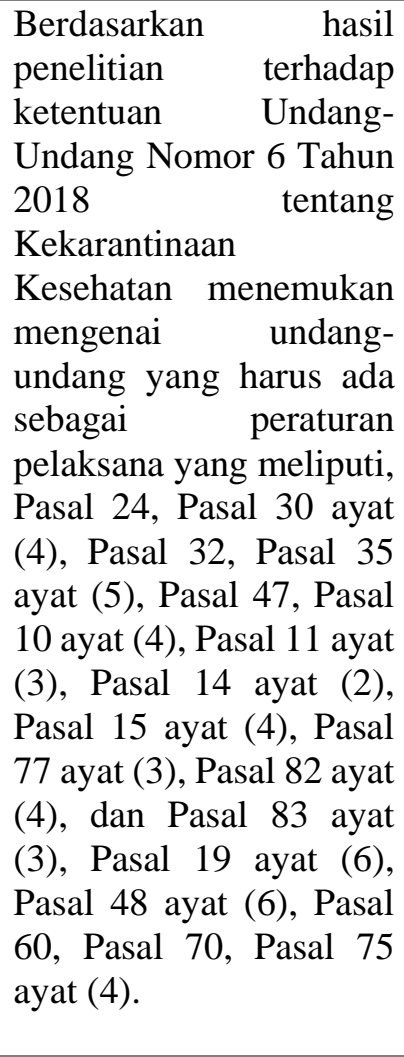 & $\begin{array}{l}\text { Membuat } \\
\text { peraturan } \\
\text { perundang } \\
\text { udangan yang } \\
\text { baik, sehingga } \\
\text { diperlukan } \\
\text { aturan tentang } \\
\text { penyusunan } \\
\text { perundang- } \\
\text { undangan } \\
\text { melalui sistem } \\
\text { dan metode, } \\
\text { yang absolut, } \\
\text { baku, dan tolak } \\
\text { ukur yang } \\
\text { mewajibkan } \\
\text { seluruh } \\
\text { lembaga yang } \\
\text { memiliki } \\
\text { wewenang } \\
\text { menyusun } \\
\text { peraturan } \\
\text { perundang- } \\
\text { undangan. }\end{array}$ \\
\hline $\begin{array}{l}\text { (Hasana } \\
\text { h et al., } \\
\text { 2020) }\end{array}$ & $\begin{array}{l}\text { Metode } \\
\text { deskripti } \\
\text { f dengan } \\
\text { bentuk } \\
\text { penelitia }\end{array}$ & $\begin{array}{l}430 \\
\text { mahasiswa } \\
\text { dari } \quad 10 \\
\text { jurusan } \\
\text { berang }\end{array}$ & $\begin{array}{l}\text { Teknik } \\
\text { pengumpulan data } \\
\text { yang dipakai } \\
\text { menggunakan } \\
\text { teknik komunikasi }\end{array}$ & $\begin{array}{l}\text { Diperoleh hasil bahwa } \\
\text { kebijakan belajar } \\
\text { dirumah yang dilakukan } \\
\text { oleh para mahasiswa, } \\
\text { mengarah pada predikat }\end{array}$ & $\begin{array}{l}\text { Terdapat } \\
\text { banyak kendala } \\
\text { ketika } \\
\text { menerapkan } \\
\text { kegiatan }\end{array}$ \\
\hline
\end{tabular}




\begin{tabular}{|c|c|c|c|c|c|}
\hline & $\begin{array}{l}\mathrm{n} \\
\text { survey. }\end{array}$ & $\begin{array}{l}\text { FTK UIN } \\
\text { Sunan } \\
\text { Gunung } \\
\text { Djati. }\end{array}$ & $\begin{array}{l}\text { daring melakukan } \\
\text { penyebaran } \\
\text { angket yang } \\
\text { memanfaatkan } \\
\text { Google Form. }\end{array}$ & $\begin{array}{l}\text { "cukup baik" di masa } \\
\text { pandemi Covid-19. }\end{array}$ & $\begin{array}{l}\text { belajar daring } \\
\text { sehingga hal } \\
\text { tersebut } \\
\text { diharap dapat } \\
\text { dijadikan } \\
\text { evaluasi di } \\
\text { masa yang akan } \\
\text { datang ketika } \\
\text { menghadapi } \\
\text { tantangan } \\
\text { serupa. }\end{array}$ \\
\hline $\begin{array}{l}\text { (Pujilest } \\
\text { ari, } \\
2020)\end{array}$ & $\begin{array}{l}\text { Studi } \\
\text { Literatur } \\
\text { dan } \\
\text { Studi } \\
\text { Lapanga } \\
\text { n }\end{array}$ & $\begin{array}{l}\text { Lingkungan } \\
\text { akademis } \\
\text { pendidikan } \\
\text { Indonesia } \\
\text { yang sudah } \\
\text { mengenal } \\
\text { dan akrab } \\
\text { dengan } \\
\text { implikasi IT } \\
\text { di bidang } \\
\text { pendidikan } \\
\text { yakni } \\
\text { Universitas } \\
\text { Pamulang, } \\
\text { pada tingkat } \\
\text { pendidikan } \\
\text { yakni SMA } \\
\text { di Tangerang } \\
\text { Selatan. }\end{array}$ & $\begin{array}{l}\text { Data yang } \\
\text { dikumpulkan } \\
\text { untuk menyusun } \\
\text { artikel, } \\
\text { berdasarkan } \\
\text { beberapa artikel } \\
\text { tentang } \\
\text { pengembangan } \\
\text { dan penerapan TI } \\
\text { di bidang } \\
\text { pendidikan dan } \\
\text { observasi } \\
\text { pengembangan TI } \\
\text { di lingkungan } \\
\text { pendidikan } \\
\text { Universitas } \\
\text { Pamulang dan } \\
\text { SMA di } \\
\text { Tangerang } \\
\text { Selatan. }\end{array}$ & 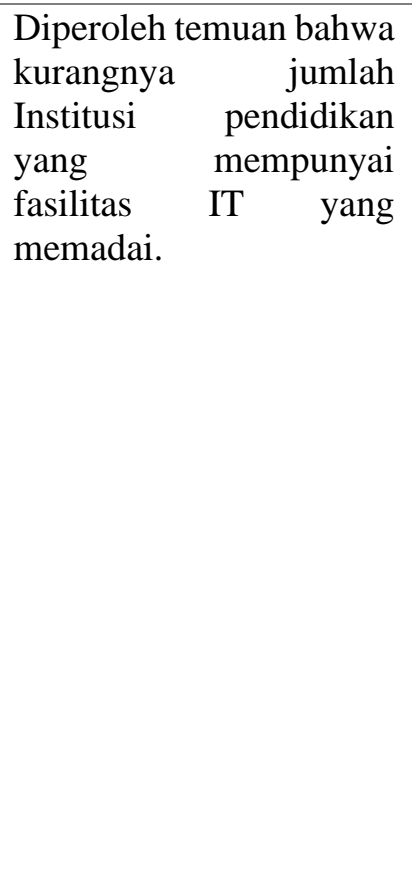 & $\begin{array}{l}\text { Diharapkan } \\
\text { masalah } \\
\text { tersebut } \\
\text { mampu } \\
\text { terselesaikan } \\
\text { seiring } \\
\text { berjalannya } \\
\text { pertumbuhan } \\
\text { telekomunikasi } \\
\text { yang semakin } \\
\text { canggih serta } \\
\text { terjangkau. }\end{array}$ \\
\hline $\begin{array}{l}\text { (Darmal } \\
\text { aksana } \\
\text { et al., } \\
2020 \text { ) }\end{array}$ & $\begin{array}{l}\text { Partisipa } \\
\text { toris } \\
\text { (partisip } \\
\text { atory } \\
\text { approac } \\
\text { h) }\end{array}$ & $\begin{array}{l}\text { Mahasiswa } \\
\text { FU UIN SGD }\end{array}$ & $\begin{array}{l}\text { Pengumpulan data } \\
\text { dilaksanakan } \\
\text { dengan pusat } \\
\text { penelitian adalah } \\
\text { mahasiswa, } \\
\text { dengan } \\
\text { menurunkan } \\
\text { aktivitas isolasi } \\
\text { serta mendorong } \\
\text { mahasiswa untuk } \\
\text { berkerja sama } \\
\text { dalam menambah } \\
\text { kegiatan } \\
\text { pembelajar } \\
\text { dengan } \\
\text { menyediakan } \\
\text { dosen ahli yang } \\
\text { sesuai, untuk } \\
\text { memantau } \\
\text { kegiatan latihan } \\
\text { guna mengetahui } \\
\text { kualitas serta } \\
\text { bergantung pada } \\
\text { feedback }\end{array}$ & $\begin{array}{l}\text { Hasil penelitian ini tidak } \\
\text { dapat digeneralisasikan } \\
\text { secara luas, karena } \\
\text { dipastikan terdapat } \\
\text { model pembelajaran } \\
\text { online yang lebih efektif } \\
\text { dan efisien. Namun, } \\
\text { studi kasus yang } \\
\text { dilakukan di FU UIN } \\
\text { SGD telah menunjukkan } \\
\text { efektivitas signifikan } \\
\text { pembelajaran online } \\
\text { meskipun sedang dalam } \\
\text { WFH akibat penyebaran } \\
\text { wabah Covid-19 }\end{array}$ & $\begin{array}{l}\text { Penelitian ini } \\
\text { merekomendas } \\
\text { ikan } \\
\text { pentingnya } \\
\text { menumbuhkan } \\
\text { ide pemimpin } \\
\text { digital } \\
\text { pendidikan } \\
\text { tinggi sebagai } \\
\text { tantangan abad } \\
21 \text { untuk } \\
\text { mewujudkan } \\
\text { pembelajaran } \\
\text { online yang } \\
\text { lebih efektif } \\
\text { seiring dengan } \\
\text { masa WFH } \\
\text { akibat pat } \\
\text { penyebaran } \\
\text { pandemic } \\
\text { Covid-19. }\end{array}$ \\
\hline
\end{tabular}




\begin{tabular}{|c|c|c|c|c|c|}
\hline & & & $\begin{array}{l}\text { penggunaan } \\
\text { platform digital. }\end{array}$ & & \\
\hline $\begin{array}{l}\text { (Abidin } \\
\text { et al., } \\
2020 \text { ) }\end{array}$ & $\begin{array}{l}\text { Studi } \\
\text { Literatur }\end{array}$ & $\begin{array}{l}\text { Studi pustaka } \\
\text { mengenai } \\
\text { aktivitas } \\
\text { belajar daring } \\
\text { berbasis } \\
\text { proyek di } \\
\text { masa } \\
\text { pandemi } \\
\text { Covid-19. }\end{array}$ & $\begin{array}{l}\text { Pengumpulan data } \\
\text { dikerjakan secara } \\
\text { studi pustaka } \\
\text { dengan } \\
\text { mengumpulkan, } \\
\text { menggabungkan, } \\
\text { mengkaji, } \\
\text { menganalisis dan } \\
\text { menyimpulkan } \\
\text { data. }\end{array}$ & $\begin{array}{l}\text { Diperoleh hasil bahwa } \\
\text { dengan menggunakan } \\
\text { sistem belajar daring } \\
\text { menunjukkan hasil yang } \\
\text { lebih baik dari pada hasil } \\
\text { belajar dengan metode } \\
\text { konvensional yang } \\
\text { dilakukan oleh } \\
\text { mahasiswa, serta sistem } \\
\text { belajar daring berbasis } \\
\text { proyek memungkinkan } \\
\text { memperbanyak peluang } \\
\text { warga pembelajar untuk } \\
\text { mengakses bahan ajar. }\end{array}$ & $\begin{array}{l}\text { Penelitian ini } \\
\text { menyarankan } \\
\text { agar semua } \\
\text { pendidik } \\
\text { maupun } \\
\text { perserta didik } \\
\text { mulai } \\
\text { memotivasi diri } \\
\text { untuk selalu } \\
\text { belajar dengan } \\
\text { menfaatkan } \\
\text { platform } \\
\text { digital, } \\
\text { sehingga } \\
\text { menghasilkan } \\
\text { proses belajar } \\
\text { mengajar } \\
\text { secara } \\
\text { maksimal yang } \\
\text { dapat } \\
\text { mempengaruhi } \\
\text { hasil belajar } \\
\text { peserta didik } \\
\text { yang optimal. }\end{array}$ \\
\hline $\begin{array}{l}\text { (Rahma } \\
\text { n \& } \\
\text { Rahayu, } \\
2020)\end{array}$ & $\begin{array}{l}\text { Penelitia } \\
\mathrm{n} \\
\text { kualitati } \\
\mathrm{f} \text { bentuk } \\
\text { penelitia } \\
\mathrm{n} \\
\text { survey. }\end{array}$ & $\begin{array}{l}\text { Mahasiswa } \\
\text { aktif yang } \\
\text { melakukan } \\
\text { kegiatan } \\
\text { belajar daring } \\
\text { dari Prodi } \\
\text { Pendidikan } \\
\text { Biologi, yaitu } \\
\text { mahasiswa: } 3 \\
\text { tangkatan } \\
\text { 2017, } 3 \\
\text { angkatan } \\
\text { 2018, } 3 \\
\text { angkatan } \\
\text { 2019, yang } \\
\text { meliputi 5 } \\
\text { perempuan } \\
\text { dan 4 laki- } \\
\text { laki, } \\
\text { sehingga } \\
\text { total } \\
\text { responden } \\
\text { adalah 9. }\end{array}$ & $\begin{array}{l}\text { Data dikumpulkan } \\
\text { dari wawancara } \\
\text { melalui telepon. } \\
\text { Berikut adalah } \\
\text { beberapa aspek } \\
\text { pertanyaanya: } \\
\text { (1) Fasilitas yang } \\
\text { dimanfaatkan } \\
\text { mahasiswa dalam } \\
\text { melakukan } \\
\text { kegiatan belajar } \\
\text { daring. Pendapat } \\
\text { (2) oleh } \\
\text { mengenai } \\
\text { efektivitas belajar } \\
\text { daring } \\
\text { mahasiswa. } \\
\text { Implementasi } \\
\text { belajar daring } \\
\text { dalam } \\
\text { mengurangi } \\
\text { penularan Covid- } \\
\text { 19 di area } \\
\text { perguruan tinggi. }\end{array}$ & 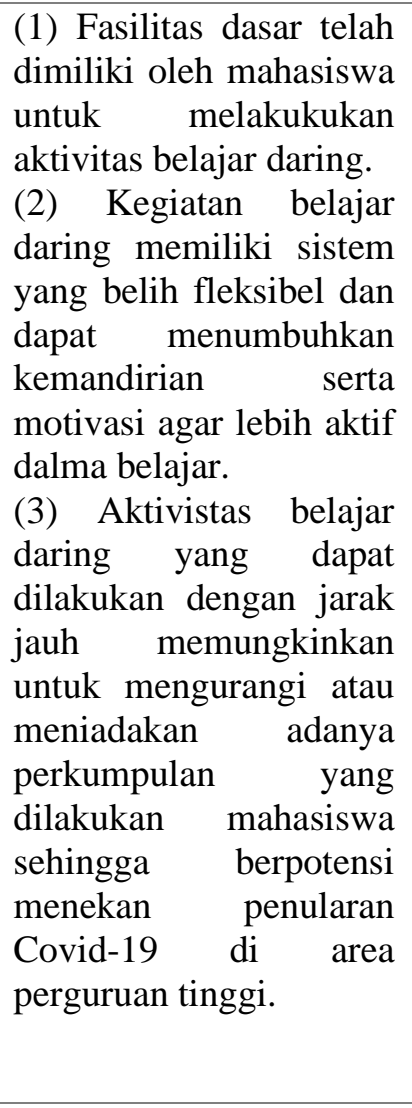 & $\begin{array}{l}\text { Penelitian ini } \\
\text { menyarakan } \\
\text { untuk } \\
\text { pembelajaran } \\
\text { online yang } \\
\text { dilakukan di } \\
\text { daerah-daerah } \\
\text { yang sulit } \\
\text { untuk } \\
\text { mengakses } \\
\text { jaringan } \\
\text { internet harus } \\
\text { dikontrol } \\
\text { karena } \\
\text { memiliki } \\
\text { potensi untuk } \\
\text { menimbulkan } \\
\text { kerumunan di } \\
\text { lingkungan } \\
\text { tertentu yang } \\
\text { memungkinkan } \\
\text { terjadi } \\
\text { peningkatan } \\
\text { penularan } \\
\text { Covid-19. }\end{array}$ \\
\hline $\begin{array}{l}\text { (Dewi, } \\
\text { 2020) }\end{array}$ & $\begin{array}{l}\text { Studi } \\
\text { Literatur }\end{array}$ & $\begin{array}{lr}\text { Artikel } & \text { dan } \\
\text { berita } & \text { yang } \\
\text { terkait } & \text { yang }\end{array}$ & $\begin{array}{l}\text { Pengumpulan data } \\
\text { diperoleh dengan } \\
\text { cara }\end{array}$ & $\begin{array}{l}\text { Pengaruh COVID-19 } \\
\text { pada penerapan sistem } \\
\text { belajar online di sekolah }\end{array}$ & $\begin{array}{l}\text { Siswa di kelae } \\
\text { I, II, dan III } \\
\text { masih belum }\end{array}$ \\
\hline
\end{tabular}




\begin{tabular}{|c|c|c|c|c|c|}
\hline & & $\begin{array}{l}\text { membahas } \\
\text { mengenai } \\
\text { akibat dari } \\
\text { Covid-19 dan } \\
\text { sistem belajar } \\
\text { online. }\end{array}$ & $\begin{array}{lr}\text { mengumpulkan } \\
\text { informasi dan data } \\
\text { dari rarita } \\
\text { maupun artikel } \\
\text { mengenai akibat } \\
\text { dari Covid-19 dan } \\
\text { sistem belajar } \\
\text { online. Sehingga } \\
\text { diperoleh } r 10 \\
\text { sumber, yang } \\
\text { meliputi } 6 \text { dari } \\
\text { berita dan } 3 \text { dari } \\
\text { artikel. }\end{array}$ & $\begin{array}{l}\text { dasar menunjukkan hasil } \\
\text { yang baik. Covid-19 } \\
\text { sangat mempengaruhi } \\
\text { pendidikan, oleh karena } \\
\text { itu dalam rangka } \\
\text { menekan penularan } \\
\text { Covid-19 diterapkannya } \\
\text { sistem belajar online } \\
\text { dengan memanfaatkan } \\
\text { beberapa aplikasi. } \\
\text { Melalui kreatifitas dari } \\
\text { guru sistem belajar } \\
\text { online ini dapat } \\
\text { menghasilkan aktivitas } \\
\text { belajar mengajar yang } \\
\text { baik dan efektif. }\end{array}$ & $\begin{array}{l}\text { mampu } \\
\text { menggunakan } \\
\text { smartphone } \\
\text { sehingga } \\
\text { membutuhkan } \\
\text { kerjasama } \\
\text { antara guru dan } \\
\text { wali murid, } \\
\text { bagi wali murid } \\
\text { yang bekerja } \\
\text { dan tidak } \\
\text { mampu untuk } \\
\text { menemani anak } \\
\text { ketika kegiatan } \\
\text { bejar maka } \\
\text { diperlukan } \\
\text { adanya jadwal } \\
\text { khusus yang } \\
\text { memungkinkan } \\
\text { anak untuk } \\
\text { belajar dengan } \\
\text { baik. Jadi, } \\
\text { sangat } \\
\text { diperlukan } \\
\text { adanya kerja } \\
\text { sama yang } \\
\text { baik antara wali } \\
\text { murid dan guru } \\
\text { sehingga } \\
\text { memaksimalka } \\
\text { n kegiatan } \\
\text { belajar online. }\end{array}$ \\
\hline $\begin{array}{l}\text { (Pratiwi } \\
\text {, 2020) }\end{array}$ & $\begin{array}{l}\text { Snowbal } \\
1 \\
\text { Throwin } \\
\mathrm{g}\end{array}$ & $\begin{array}{l}5 \text { partisipan } \\
\text { ( } 2 \text { dosen dan } \\
3 \text { mahasiswa) } \\
\text { Universitas } \\
\text { Kristen Satya } \\
\text { Wacana }\end{array}$ & \begin{tabular}{lr}
\multicolumn{2}{l}{ Pemerolehan data } \\
dalam penelitian \\
ini dilakukan \\
dengan rara \\
wawancara online \\
melalui & Whatsapp \\
yang dilakukan \\
dengan \\
mahasiswa dan & 2 \\
dosen & di \\
Universitas & \\
Kristen & Satya \\
Wacana &
\end{tabular} & $\begin{array}{l}\text { Pada masa pandemi } \\
\text { COVID-19, Universitas } \\
\text { Kristen Satya Wacana } \\
\text { memiliki satu solusi } \\
\text { untuk pelaksanaan } \\
\text { pembelajarannya, yakni } \\
\text { menggunakan } \\
\text { pembelajaran online } \\
\text { dengan tujuan } \\
\text { mengganti metode } \\
\text { pembelajaran secara } \\
\text { tatap muka yang telah } \\
\text { dilakukan sebelumnya. } \\
\text { Pembelajaran online } \\
\text { yang dilakukan mampu } \\
\text { berjalan dengan lancar } \\
\text { meskipun terdapat } \\
\text { beberapa kendala. } \\
\text { Apilkasi yang } \\
\text { digunakan dalam } \\
\text { pelaksanaan } \\
\text { pembelajaran online ini } \\
\text { seperti Google }\end{array}$ & $\begin{array}{l}\text { Dilakukannya } \\
\text { evaluasi berupa } \\
\text { perbaikan } \\
\text { dalam } \\
\text { pengemasan } \\
\text { pembelajaran } \\
\text { secara online } \\
\text { pada } \\
\text { pembelajaran } \\
\text { semester } \\
\text { selanjutnya } \\
\text { dengan cara } \\
\text { pemberian } \\
\text { kuota belajar } \\
\text { kepada setiap } \\
\text { mahasiswa } \\
\text { guna } \\
\text { membantu } \\
\text { mahasiswa } \\
\text { dalam } \\
\text { mengikuti } \\
\text { pembelajaran } \\
\text { dengan lacar }\end{array}$ \\
\hline
\end{tabular}




\begin{tabular}{|c|c|c|c|c|c|}
\hline & & & & $\begin{array}{l}\text { Classroom, Zoom, dan } \\
\text { Schoology. }\end{array}$ & $\begin{array}{l}\text { tanpa merasa } \\
\text { terbebani } \\
\text { masalah } \\
\text { ekonomi } \\
\text { mahasiswa di } \\
\text { Universitas } \\
\text { Kristen Satya } \\
\text { Wacana. }\end{array}$ \\
\hline $\begin{array}{l}\text { (Purwa } \\
\text { nto et } \\
\text { al., } \\
2020 \text { ) }\end{array}$ & $\begin{array}{l}\text { Studi } \\
\text { kasus } \\
\text { kualitati } \\
\text { f }\end{array}$ & $\begin{array}{l}\text { Purposive } \\
\text { sampling, } 6 \\
\text { responden } \\
\text { orang guru } \\
\text { dan wali } \\
\text { murid } \\
\text { Sekolah } \\
\begin{array}{l}\text { Dasar di } \\
\text { Tangerang }\end{array}\end{array}$ & $\begin{array}{l}\text { Pengumpulan data } \\
\text { dalam penelitian } \\
\text { ini didapatkan } \\
\text { dengan cara } \\
\text { melakukan } \\
\text { wawancara semi- } \\
\text { terstruktur dengan } \\
\text { menggunakan } \\
\text { daftar pertanyaan } \\
\text { yang disusun } \\
\text { untuk wawancara } \\
\text { dikembangkan } \\
\text { dari literatur } \\
\text { terkait. }\end{array}$ & $\begin{array}{l}\text { Pelaksaanan } \\
\text { pembelajaran daring ini } \\
\text { berdampak pada guru } \\
\text { dan murid, yakni } \\
\text { mereka dipaksan untuk } \\
\text { melakukan } \\
\text { pembelajaran dengan } \\
\text { interaksi jarak jauh } \\
\text { tanpa adanya sarana dan } \\
\text { prasarana yang } \\
\text { memadai. Diperlukan } \\
\text { adaptasi baru antara } \\
\text { guru dan murid untuk } \\
\text { melaksanakan } \\
\text { pembelajaran jarak jauh } \\
\text { dikarenakan akan } \\
\text { mempengaruhi tingkat } \\
\text { kepemahaman dan } \\
\text { minat belajar murid } \\
\text { dalam menerima materi } \\
\text { yang disampaikan. } \\
\text { Dampak lainnya yang } \\
\text { dirasakan adalah } \\
\text { pembekakan dalam } \\
\text { bidang ekonomi dari } \\
\text { guru dan orang tua } \\
\text { murid, dikarenakan } \\
\text { kebutuhan penggunaan } \\
\text { kuota yang makin } \\
\text { meningkat daripada } \\
\text { sebelumnya. } \\
\text { Pembelajaran online } \\
\text { membutuhkan } \\
\text { kemampuan guru dalam } \\
\text { bidang teknologi, } \\
\text { namun dalam penelitian } \\
\text { ini mengungkapkan } \\
\text { bahwa tidak semua guru } \\
\text { memiliki kemampuan } \\
\text { dalam bidang teknologi, } \\
\text { sehingga akan } \\
\text { mempengaruhi kualitas } \\
\text { pembelajaran. }\end{array}$ & $\begin{array}{l}\text { Pelaksanaan } \\
\text { langkah } \\
\text { persiapan } \\
\text { dalam } \\
\text { pembelajaran } \\
\text { online dinilai } \\
\text { sangat penting, } \\
\text { seperti } \\
\text { persiapan } \\
\text { fasilitas } \\
\text { pendukung } \\
\text { pembelajaran, } \\
\text { persiapan } \\
\text { kompetensi } \\
\text { pembelajaran } \\
\text { yang akan } \\
\text { dilakukan dan } \\
\text { juga } \\
\text { pelaksanaan } \\
\text { pelatihan untuk } \\
\text { siswa, orang } \\
\text { tua dan guru. } \\
\text { Jika } \\
\text { pelaksanaan } \\
\text { langkah } \\
\text { persiapan ini } \\
\text { tidak } \\
\text { dilakukan, } \\
\text { maka akan } \\
\text { mempengaruhi } \\
\text { tingkat hasil } \\
\text { belajar siswa. }\end{array}$ \\
\hline
\end{tabular}

\section{HASIL DAN PEMBAHASAN}

Setelah melakukan proses pencarian artikel dengan menggunakan metode seperti yang dijelaskan pada uraian diatas, didapatkan 10 artikel yang relevan. Selanjutnya 10 artikel terpilih akan dianalisis dengan seksama dan 
menemukan beberapa tema penelitian yang telah dilakukan oleh para peneliti sebelumnya. Kemudian hasil analisis dikelompokan sesuai dengan topik sebagai berikut:

\section{Ulasan Literatur Tentang Pandemi COVID- 19}

Pandemi COVID-19 merupakan hal baru yang menjadi perhatian di dunia saat ini.
Sehingga ditemukan beberapa literatur yang membahas mengenai COVID-19. Sehingga didapatkan hasil berupa pengetahuan tentang apa itu COVID-19, cara penularan hingga cara pencegahannya sesuai dengan ketetapan pemerintah Indonesia. Hal ini dianggap perlu karena dapat digunakan untuk sumber edukasi pada masyarakat mengenai penyakit yang tergolong baru.

Tabel 2. Penelitian Tentang Topik Ulasan Literatur Pandemi COVID-19

\begin{tabular}{lll}
\hline No & \multicolumn{1}{c}{ Ulasan } & Peneliti \\
\hline 1 & $\begin{array}{l}\text { Membahas tentang pencegahan penularan virus COVID-19 } \\
\text { dengan menerapkan Perilaku Hidup Bersih dan Sehat (PHBS), }\end{array}$ & (Karo, 2020) \\
& yakni mencuci tangan sesuai anjuran WHO, etika batuk, dan & \\
& menjaga kesehatan serta sistem imunisasi tubuh. & \\
& Berisi mengenai pembentukan peraturan pencegahan COVID-19 & \\
& yang dilakukan oleh pemerintah Indonesia, yang salah satunya & \\
& adalah aturan mengenai Pembatasan sosial berskala besar & \\
& menurut Pasal 1 angka UU Kekarantinaan Kesehatan. Yang & (Telaumbanua, \\
& menyebutkan bahwa, "Pembatasan kegiatan tertentu penduduk & 2020) \\
& $\begin{array}{l}\text { dalam suatu wilayah yang diduga terinfeksi penyakit dan/atau } \\
\text { terkontaminasi sedemikian rupa untuk mencegah kemungkinan } \\
\text { penyebaran penyakit atau kontaminasi.". Sehingga berdampak } \\
\text { pada sistem pembelajaran secara tatap muka di Indonesia. }\end{array}$ & \\
\hline
\end{tabular}

Kegiatan Pembelajaran Online Di Masa Pandemi COVID-19

Pandemi COVID-19 menyebabkan perubahan aktivitas di berbagai bidang, salah satunya bidang pendidikan. Sehingga ditemukan 4 topik penelitian yang bertujuan mengkaji kegiatan pembelajaran online di era pandemi COVID-19 seperti yang ditunjukkan pada tabel
2. Dari hasil analisis memaparkan bahwa kegiatan pembelajaran online merupakan salah satu solusi pembelajaran di masa COVID-19. Pembelajaran online tersebut bertujuan sebagai alternatif pembelajaran secara konvensional dengan tatap muka untuk mempermudah proses pembelajaran di masa pandemi COVID-19.

Tabel 3. Tujuan Penelitian dari Pembelajaran Online Di Masa Pandemi COVID-19

\begin{tabular}{lll}
\hline No & \multicolumn{1}{c}{ Tujuan } & \multicolumn{1}{c}{ Peneliti } \\
\hline 1 & $\begin{array}{l}\text { Mendapatkan data informasi secara objektif mengenai aktivitas } \\
\text { pembelajaran online mahasiswa FTK UIN sunan Gunung Djati } \\
\text { yang dilakukan sesuai dengan kebijakan untuk belajar dari rumah }\end{array}$ & (Hasanah et al., 2020) \\
& $\begin{array}{l}\text { selama masa tanggap darurat COVID-19. } \\
\text { Menganalisis tentang pembelajaran online di masa works from }\end{array}$ & \\
& $\begin{array}{l}\text { home (WFH) dikarenakan adanya penyebaran virus COVID-19 } \\
\text { seiring adanya tantangan pendidikan yang sesuai dengan }\end{array}$ & $\begin{array}{l}\text { (Darmalaksana en } \\
\text { al., 2020) }\end{array}$ \\
& $\begin{array}{l}\text { kemajuan abad-21. } \\
\text { Mengupas secara teoritis pengaruh pembelajaran online berbasis }\end{array}$ & \\
& $\begin{array}{l}\text { proyek di masa pandemi Covid-19 terhadap kebijakan belajar di } \\
\text { rumah berdasarkan studi pustaka. }\end{array}$ & (Abidin et al., 2020) \\
& $\begin{array}{l}\text { Memperoleh gambaran upaya penekanan penyebaran Covid-19 } \\
\text { di lingkungan kampus Universitas Sulawesi Barat (Unsulbar) }\end{array}$ & (Rahman \& Rahayu, \\
& $\begin{array}{l}\text { Prodi Pendidikan Biologi Fakultas Keguruan dan Ilmu } \\
\text { Pendidikan (FKIP) dengan penerapan pembelajaran online. }\end{array}$ & \\
\hline
\end{tabular}




\begin{abstract}
Dampak COVID-19
Pembelajaran Secara Online

Terhadap

COVID-19 memiliki dampak yang cukup berpengaruh pada bidang pendidikan di Indonesia. Terlebih pada pembelajaran online yang semakin berkembang sebagai tanggapan

adanya peraturan pemerintah Indonesia mengenai Pembatasan Sosial Berskala Besar (PSBB), yang tidak memungkinkan terjadinya pembelajaran secara tatap muka. Adapun dampak-dampak tersebut dapat dilihat pada tabel 4 dibawah ini.
\end{abstract}

Tabel 4. Penelitian Tentang Topik Pembelajaran Secara Online di era pandemi COVID-19

\begin{tabular}{llc}
\hline No & Dampak & Peneliti \\
\hline 1 & Pembelajaran online di sekolah dasar membantu pemerintah untuk memutus & \\
rantai penularan Covid-19. Pembelajaran yang biasanya dilakukan di sekolah & (Dewi, \\
& sekarang beralih pada pembelajaran di rumah, tetapi proses pembelajaran & 2020) \\
masih dapat dilakukan dengan baik menggunakan berbagai macam platform & \\
belajar online. & \\
Guru dan siswa merasa dipaksa untuk beradaptasi menggunakan pembelajaran & \\
jarak jauh tanpa didukung oleh sarana dan prasarana yang memadahi di rumah. & \\
Pembelajaran online secara tidak langsung mempengaruhi daya serap belajar & \\
siswa serta menyebabkan rasa jenuh oleh guru dan siswa karena sekolah & (Purwanto \\
diliburkan terlalu lama. Terhadap orang tua dan guru berdampak pada & et al., 2020) \\
penambahan biaya pembelian kuota internet, serta tidak semua guru mampu & \\
menggunakan teknologi dan hal ini akan mempengaruhi kualitas program & \\
belajar mengajar. & \\
Pembelajaran jarak jauh secara daring dapat berdampak negatif karena & \\
memiliki beberapa kelemahan yaitu penggunaan internet membutuhkan & \\
infrastruktur yang memadai, dana yang besar, dan beberapa kendala & \\
komunikasi melalui internet. Serta berdampak positif karena memiliki & \\
beberapa kelemahan yakni kadar interaksi antara mahasiswa dengan dosen & (Pratiwi, \\
meningkat, dapat mencakup siswa (mahasiswa) secara luas (potential to reach & 2020) \\
a global audience), pembelajaran dapat dilakukan dimanapun dan kapanpun & \\
(time and place flexibility), serta mempermudah meningkatkan dan & \\
penyimpanan materi pembelajaran (easy updating of content as well as & \\
archivable capabilities). & \\
Internet bersifat fleksibel yang artinya memudahkan siswa untuk \\
memanfatkan program pendidikan atau sumber belajar yang ada di internet & \\
secara online kapanpun dan dimanapun, sehingga tidak adanya kendala ruang \\
dan waktu dalam belajar. Penerapan TI dapat digunakan sebagai sarana
\end{tabular}

\section{Lembaga/Instansi}

Hasil tinjauan literatur juga menunjukkan terdapat beberapa instansi pendidikan di Indonesia yang telah dijadikan sebagai obyek penelitian dalam pelaksanaan pembelajaran online di masa pandemi COVID-19, yang dapat dilihat pada tabel 5 .

Tabel 5. Penelitian Tentang Lembaga/Instansi yang Melaksanakan Pembelajaran Online Di Masa Pandemi COVID-19

\begin{tabular}{lll}
\hline No & Objek Penelitian & \multicolumn{1}{c}{ Peneliti } \\
\hline 1 & Sekolah Dasar & (Dewi, 2020) \\
2 & Sekolah Dasar di wilayah Tangerang & (Purwanto et al., 2020) \\
3 & Perguruan Tinggi Kristen di Indonesia & (Pratiwi, 2020) \\
4 & FTK UIN Sunan Gunung Djati & (Hasanah et al., 2020)
\end{tabular}


$5 \quad$ UIN Sunan Gunung Djati Bandung

6 Prodi Pendidikan Biologi, Fakultas Keguruan

dan Ilmu Pendidikan (FKIP), Universitas

(Darmalaksana et al., 2020)

Sulawesi Barat

Berdasarkan pada pengelompokkan artikel diatas, maka diperoleh jawaban mengenai research question pada penelitian ini, yang meliputi:

(1) Dengan banyaknya penelitian yang mengkaji tentang kegiatan pembelajaran online di era pandemi COVID-19 yang dipaparkan pada tabel 2 dan banyaknya instansi pendidikan yang melaksanakan pembelajaran secara online yang dapat dilihat pada tabel 4, maka dapat dikatakan bahwa pembelajaran online di era pandemi COVID-19 sangat memacu pertumbuhan pembelajaran online saat ini. Hal tersebut juga ditandai dengan berkembangnya berbagai platform pembelajaran, baik berupa aplikasi, web/blog, vidio, podcast ataupun yang lain (Hanifah Salsabila et al., 2020)

(2) Sejak diberlakukannya sistem work from home pada tanggal 16 Maret 2020 yang menyebabkan instansi pendidikan melaksanakan proses belajar mengajar di rumah secara online. Namun terdapat beberapa kendala di lapangan, sehingga pemerintah melakukan evaluasi yang menghasilkan kebijakan berupa pembukaan sekolah di zona hijau dan kuning dengan berbagai syarat dan penerapan protokol kesehatan. Hingga saat penelitian ini dikerjakan, pemerintah mengeluarkan kebijakan baru dari hasil evaluasi sebelumnya yakni kewenangan pembukaan sekolah diberikan ke pemda karena dinilai paling mengerti situasi di lapangan (Fey, 2020).

(3) Pertumbuhan sistem belajar online sebenarnya memudahkankan siswa dan guru maupun dosen dalam proses melakukan kegiatan belajar mengajar, sebagai tanggapan dari kebijakan pemerintah tentang Pembatasan Sosial Berskala Besar (PSBB) di masa pandemi COVID-19. Hal tersebut dapat dilihat tabel 3 yang memaparkan dampak dari penerapan metode pembelajaran ini. Yaitu dengan adanya pembelajaran online pengajar dan pelajar dapat berinteraksi kapanpun dan dimanapun. Namun, nyatanya pengajar dan pelajar belum terbiasa dengan sebuah sistem baru yang menyebabkan pelajar merasa terpaksa melakukan kelas online dan merasa jenuh karena pembelajaran hanya dilakukan di rumah. Sehingga, dapat disimpulkan bahwa pertumbuhan pembelajaran secara online dapat memudahkan siswa dan guru maupun dosen dalam proses kegiatan belajar mengajar di masa pandemi COVID-19, namun jika dinilai dari perubahan sikap siswa hal tersebut menunjukkan sisi negatif yang dapat berpengaruh pada menurunya kualitas belajar siswa (Rosali, 2020)

\section{KESIMPULAN}

Berdasarkan dari hasil kajian yang telah dilakukan pada beberapa artikel dengan topik berdasarkan kata kunci yang dipilih, diperoleh 10 artikel yang selanjutnya di kelompokkan menjadi 4 berdasarkan klasifikasi topik. Dari kajian parsial dan lengkap dari 4 kelompok ini diketahui bahwa kajian yang membahas mengenai kebijakan pemerintah dalam memberlakuan pembelajaran secara online masih sedikit. Selain itu, diperoleh hasil penelitian yang meliputi:

1. Pembelajaran online di era pandemi COVID-19 sangat memacu pertumbuhan pembelajaran online saat ini.

2. Adanya kemungkinan pengevaluasian pembelajaran online oleh pemerintah mengingat terdapat urgensi aturan dan kebijakan, yang sewaktu-waktu mungkin akan mengalami perubahan dan membutuhkan pengevaluasian untuk pengambilan kebijakan baru yang lebih baik.

3. Pertumbuhan pembelajaran secara online sangat memudahkan dalam proses belajar mengajar, namun jika dinilai dari perubahan sikap siswa hal tersebut menunjukkan sisi negatif yang dapat berpengaruh pada menurunya kualitas belajar siswa.

Adapun saran yang perlu dikembangkan adalah adanya kebijakan ataupun metode yang dapat membantu meningkatkan kualitas belajar siswa menjadi lebih optimal di masa pandemi 
COVID-19.

\section{DAFTAR PUSTAKA}

Abidin, Z., Rumansyah, \& Arizona, K. (2020). Pembelajaran Online Berbasis Proyek Salah Satu Solusi Kegiatan Belajar Mengajar Di Tengah Pandemi COVID-19. https://doi.org/10.29303/jipp.v5i1.111

Darmalaksana, W., Hambali, R. Y. A., Masrur, A., \& Muhlas. (2020). Analisis Pembelajaran Online Masa WFH Pandemic Covid-19 sebagai Tantangan Pemimpin Digital Abad 21. 1-12. http://digilib.uinsgd.ac.id/30434/1/110420 2015.30 KTI.pdf

Dewi, W. A. F. (2020). Dampak COVID-19 Terhadap Implementasi Pembelajaran Daring di Sekolah Dasar. 2(1), 55-61. https://edukatif.org/index.php/edukatif/arti cle/view/89

Fey. (2020). Pembelajaran Jarak Jauh: Anies Pelopori, Nadiem Sudahi. CNN Indonesia. https://www.cnnindonesia.com/nasional/2 0201209093854-20-

579760/pembelajaran-jarak-jauh-aniespelopori-nadiem-sudahi

Hanifah Salsabila, U., Irna Sari, L., Haibati Lathif, K., Puji Lestari, A., \& Ayuning, A. (2020). Peran Teknologi Dalam Pembelajaran Di Masa Pandemi Covid-19. Al-Mutharahah: Jurnal Penelitian Dan Kajian Sosial Keagamaan, 17(2), 188$198 . \quad$ https://doi.org/10.46781/almutharahah.v17i2.138

Hasanah, A., Sri Lestari, A., Rahman, A. Y., \& Danil, Y. I. (2020). Analisis Aktivitas Belajar Daring Mahasiswa Pada Pandemi COVID-19. Karya Tulis Ilmiah (KTI) Masa Work From Home (WFH) Covid-19 UIN Sunan Gunung Djati Bandung Tahun 2020 , 4-8. http://digilib.uinsgd.ac.id/id/eprint/30565

Jayawardana, H. B. A. (2017). Paradigma Pembelajaran Biologi Di Era Digital. Jurnal Bioedukatika, 5(1), 12. https://doi.org/10.26555/bioedukatika.v5i1 .5628

Karo, M. B. (2020). Perilaku Hidup Bersih dan Sehat (PHBS). Jurnal Keperawatan Komunitas, 01(01), 40-47. W Saputro, LY Budiarti, H Herawati - Dunia Keperawatan, 2016 - ppjp.unlam.ac.id

Pratiwi, E. W. (2020). Dampak Covid-19 Terhadap Kegiatan Pembelajaran Online
Di Sebuah Perguruan Tinggi Kristen di Indonesia. 34(1).

Pujilestari, Y. (2020). Dampak Positif Pembelajaran Online Dalam Sistem Pendidikan Indonesia Pasca Pandemi Covid-19. 4, 49-56. http://journal.uinjkt.ac.id/index.php/adalah /article/view/15394

Purwanto, A., Pramono, R., Asbari, M., Santoso, P. B., Wijayanti, L. M., Hyun, C. C., \& Putri, R. S. (2020). Studi Eksploratif Dampak Pandemi COVID-19 Terhadap Proses Pembelajaran Studi Eksploratif Dampak Pandemi COVID-19 Terhadap Proses Pembelajaran Online di Sekolah Dasar. April.

Rahman, \& Rahayu, S. (2020). Pembelajaran Online di Tengah Pandemi Covid-19. 02(02), 81-89. https://ojs.unsulbar.ac.id/index.php/ijes/art icle/download/659/369/

Rosali, E. S. (2020). Aktifitas Pembelajaran Daring Pada Masa Pandemi Covid -19 Di. Geography Science Education Journal (GEOSEE), 1(1), 21-30. https://www.researchgate.net/publication/ 340917125_Kendala_Pelaksanaan_Pembe lajaran_Jarak_Jauh_PJJ_dalam_Masa_Pan demi/stats

Telaumbanua, D. (2020). Urgensi Pembentukan Aturan Terkait Pencegahan Covid-19 di Indonesia. Jurnal Pendidikan, Sosial, Dan Agama, 12(01), 59-70. https://doi.org/10.37680/qalamuna.v12i01. 290 